\title{
Research Paper \\ Comparison of the Effectiveness of Mindfulness Therapy, Neurofeedback and Therapy Based on SPARK Perceptual-Motor Exercises on the Difficulty of Emotion Regulation in Children with Attention Deficit Hyperactivity Disorder (ADHD)
}

\author{
Zahra Bot Shekan ${ }^{1}$, Yousef Gorji ${ }^{* 2}$, Hamid Zahedi ${ }^{3}$, Zohreh Raisi ${ }^{4}$, Hossein Zarrin ${ }^{5}$ \\ 1. Ph.D. Student in General Psychology, Department of Psychology, Najafabad Branch, Islamic Azad University, Najafabad, Iran \\ 2. Assistant Professor, Department of Psychology, Najafabad Branch, Islamic Azad University, Najafabad, Iran And Assistant \\ Professor, Department of Psychology, Khomeini Shahr Branch, Islamic Azad University, Khomeini Shahr, Iran \\ 3. Assistant Professor, Department of Sport Science, Najafabad Branch, Islamic Azad University, Najafabad, Iran \\ 4. Assistant Professor, Department of Psychology, Najafabad Branch, Islamic Azad University, Najafabad, Iran \\ 5. Assistant Professor, Department of Psychology, Khomeini Shahr Branch, Islamic Azad University, Khomeini Shahr, Iran
}

Citation: Bot Shekan Z, Gorji Y, Zahedi H, Raisi Z, Zarrin H. Comparison of the Effectiveness of Mindfulness Therapy, Neurofeedback and Therapy Based on SPARK Perceptual-Motor Exercises on the Difficulty of Emotion Regulation in Children with Attention Deficit Hyperactivity Disorder (ADHD). J Child Ment Health. $2021 ; 7$ (4) :61-75.

URL: http://childmentalhealth.ir/article-1-973-en.html
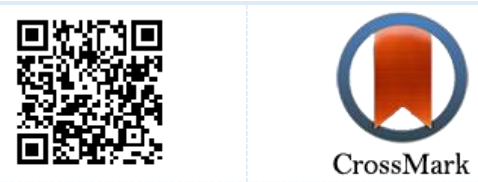

$10.52547 / \mathrm{jcmh} \cdot 7.4 .5$

20.1001.1.24233552.1399.7.4.4.2

\section{A R T I C L E I N F O}

\section{Keywords:}

Mindfulness, neurofeedback, SPARK perceptualmotor exercises, emotion regulation, attention deficit hyperactivity disorder (ADHD)

Received: 11 mar 2020 Accepted: 26 Aug 2020 Available: 13 Mar 2021

\section{A B S T R A C T}

Background and Purpose: Attention Deficit Hyperactivity Disorder (ADHD) is one of the most common neurodevelopmental disorders in childhood that affects a wide range of functions, including emotion regulation. This study aimed to compare and determine the effectiveness of mindfulness therapy, neurofeedback and therapy based on SPARK perceptual-motor exercises on emotion regulation in children with ADHD.

Method: This study was a quasi-experimental research with control group design, including pre-test, post-test, and follow-up. The study population included all children with ADHD in Isfahan during April to September 2019, among them 60 were selected by purposive sampling and then randomly assigned to any of the four groups: mindfulness therapy, neurofeedback, therapy based on SPARK perceptual-motor exercises, and the control group. The experimental groups underwent the therapies for 10 weeks, while the control group received no intervention. To collect the data, Difficulties in Emotion Regulation Scale of Bunford et al. (2018) was used. The collected data were analyzed by repeated measures ANOVA in SPSS.

Results: The findings showed that in the post-test phase, there was a significant difference between the experimental groups and the control group $(\mathrm{p}<0.01)$. Comparing the groups, it was found that mindfulness intervention was more effective than neurofeedback $(\mathrm{p}<0.05)$, but no significant difference was observed between mindfulness therapy and SPARK ( $p>0.05$ ). Also, findings of the follow-up phase showed that the effectiveness endured in the mindfulness and SPARK groups $(p<0.01)$ but the effect of neurofeedback decreased over time ( $p>0.05)$.

Conclusion: Based on the results, it can be stated that mindfulness and the therapy based on SPARK perceptual-motor exercises reduce the difficulty in emotion regulation through increasing the clarity and acceptance of emotions and regulating the nervous connections respectively.

* Corresponding author: Yousef Gorji, Assistant Professor, Department of Psychology, Najafabad Branch, Islamic Azad University, Najafabad, Iran And Assistant Professor, Department of Psychology, Khomeini Shahr Branch, Islamic Azad University, Khomeini Shahr, Iran.

E-mail: Gorji@iaukhsh.ac.ir

Tel: (+98) 313225913

2476-5740/ (C) 2021 The Authors. This is an open access article under the CC BY-NC-ND license

(https://creativecommons.org/licenses/by-nc-nd/4.0/). 


\section{Extended Abstract}

\section{Introduction}

One of the most common neurodevelopmental disorders in childhood is Attention Deficit Hyperactivity Disorder (ADHD) (1) which affects more than five percent of children who present symptoms like sustained attention, irritability, and hyperactivity (2). Its common comorbidities include mood, anxiety, behavioral, learning, and substance use disorders (3). Emotion regulation problems in these children are also associated with social problems. In fact, these children experience problems in discipline, school expulsion, and social exclusion because they often use aggression to regulate their anger (5).

In recent years, therapists have shown great interest in using new psychological approaches to increase adaptation in children. One of the newest and most effective forms of this type of treatment is mindfulness (12). Kiani\& Hadianfard (17), Roemer, Williston and Rollins (18), Butler et al. (19), Slutsky, Rahl, Lindsay, \& Creswell (20) and Britton, Shahar, Szepsenwol and Jacobs (21) showed that mindfulness is an effective method in improving emotion regulation.

On the other hand, among the non-pharmacological interventions for ADHD, neurofeedback has been considered as a promising strategy since the early 1970s (22). The main idea and theoretical foundation of neurofeedback is based on the fact that one can control his or her brain activity and direct his or her abnormal neuro-cerebral activity pattern through conditioning. By decreasing the slow waves (theta) and increasing the rapid waves (beta) in children with ADHD, neurofeedback results in the formation of more normal waves (22-25).

Another therapy for ADHD, proposed by psychiatrists and sports physiologists to prevent and treat behavioral disorders in children and adolescents, is perceptual-motor exercises (26). However, Chen points out the contradictory results of the effectiveness of sports activities on behavioral disorders and associated failures in children (28). The findings of Bishop (29) showed that SPARK perceptual-motor exercises are an effective training for emotion regulation in students and can provide the basis for reducing the difficulties in emotion regulation.

According to the foregoing paragraphs and based on the researches done in the field of treating the individuals with ADHD, it can be stated that a relatively small number of people with ADHD receive the therapy appropriate for reducing the difficulty in emotion regulation and the treatments rarely target the central symptoms of the disorder. Therefore, the present study was conducted to compare and determine the effectiveness of interventions based on mindfulness, neurofeedback, and SPARK perceptual-motor exercises on emotion regulation in second grade primary students with ADHD.

\section{Method}

This study was a quasi-experimental research with follow-up pretest-posttest design, including three experimental groups of mindfulness, neurofeedback, and therapy based on SPARK perceptual-motor exercises. The study population included all second grade primary students with ADHD in Isfahan during April to September 2019, among them 60 were selected by purposive sampling and then randomly assigned to any of the four groups: mindfulness therapy, neurofeedback, therapy based on SPARK perceptual-motor exercises, and the control group. The three experimental groups (15 students per group) received the mindfulness therapy (13) for 10 weeks (ten 60-min sessions), neurofeedback (36) (four 45-min sessions) and SPARK motor-perceptual exercises (35) (thirty 40min sessions) conducted by the therapist in Espadana counseling center in Isfahan; while the control group received no intervention.

To measure the difficulty of emotion regulation, Difficulties in Emotion Regulation Scale of Bunford et al. (34) was used. This scale includes 36 items and 
6 components, i.e. non-acceptance of emotional responses, difficulties engaged in goal-directed behaviors, impulse control difficulties, lack of emotion awareness, limited access to emotion regulation strategies, and lack of emotion clarity. It was responded by the parents of children with
ADHD and its reliability in the present study was estimated to be 0.88 using Cronbach's alpha. The collected data were analyzed by repeated measures ANOVA in SPSS-24 software.

\section{Results}

Table 1: Descriptive inferential statistics of dependent variables at the pre-test, post-test and 45-day follow-up phase

\begin{tabular}{|c|c|c|c|c|c|c|c|c|c|c|c|c|}
\hline \multirow{2}{*}{ Phase } & \multicolumn{2}{|c|}{ Control group } & \multicolumn{2}{|c|}{ Mindfulness } & \multicolumn{2}{|c|}{ Neurofeedback } & \multicolumn{2}{|c|}{ SPARK } & \multicolumn{2}{|c|}{ Difference } & \multirow{2}{*}{$\eta^{2}$} & \multirow{2}{*}{ Power of test } \\
\hline & $\mathbf{M}$ & SD & M & SD & M & SD & M & SD & $\mathbf{F}$ & $\mathbf{P}$ & & \\
\hline Pretest & 122.07 & 9.36 & 122.67 & 7.68 & 121.67 & 7.87 & 118.60 & 8.70 & 0.69 & 0.56 & \multirow{3}{*}{0.64} & \multirow{3}{*}{1.00} \\
\hline Posttest & 121.87 & 7.98 & 102.60 & 5.30 & 112.07 & 6.75 & 106.53 & 7.24 & 22.09 & 0.001 & & \\
\hline Follow-up & 120.0 & 8.81 & 106.33 & 4.70 & 114.07 & 8.77 & 107.13 & 7.61 & 10.57 & 0.001 & & \\
\hline
\end{tabular}

Table 1 shows the mean and standard deviation of the variable of emotion regulation difficulties at pretest, post-test, and follow-up phases. As the findings of one-way analysis of variance in the first row of the table show, there was no significant difference between the experimental groups at the pretest phase $(\mathrm{P}=0.056, \mathrm{~F}=0.069)$. These findings show that in addition to being normal, the dispersion and central tendency indices were equal between the groups; therefore, it can be said that random assignment to the groups did not cause any difference. Also, the normality of the data was examined by ShapiroWilkes test and it was found that the null hypothesis of the research indicating the normality of the data was confirmed $(p>0.05)$. The results of Levin test at the pre-test phase $(\mathrm{P}=0.85, \mathrm{~F}=0.027)$ showed that the variance was homogeneous. In addition, the results of analysis of variance showed that there was a significant difference between the groups in terms of emotion regulation difficulties $\left(\eta^{2}=-0.46, \mathrm{P}=0.01\right.$, $\mathrm{F}=16.14)$.

Table 2: Results of Benferroni pairwise comparison of the groups per phase

\begin{tabular}{|c|c|c|c|c|c|c|}
\hline Phase & Mindfulness \& control group & $\begin{array}{c}\text { Neurofeedback } \\
\text { \& control } \\
\text { group } \\
\end{array}$ & $\begin{array}{c}\text { SPARK \& } \\
\text { Neurofeedback }\end{array}$ & $\begin{array}{l}\text { Mindfulness \& } \\
\text { Neurofeedback }\end{array}$ & $\begin{array}{l}\text { Mindfulness } \\
\text { \& SPARK }\end{array}$ & $\begin{array}{l}\text { Neurofeedback } \\
\text { \& SPARK }\end{array}$ \\
\hline Pre-test & 0.001 & 0.001 & 0.001 & 0.001 & 0.335 & 0.324 \\
\hline Follow-up & 0.001 & 0.242 & 0.001 & 0.048 & 1.0 & 0.119 \\
\hline
\end{tabular}

Benferroni pairwise comparison showed that there was a significant difference between the control group and the experimental groups of mindfulness ( $\mathrm{p}$ $<0.01)$, neurofeedback $(\mathrm{p}<0.01)$ and SPARK $(\mathrm{p}<0.01)$ at the post-test phase. Other findings showed that mindfulness therapy was more effective than neurofeedback therapy ( $p<0.05$ ), however no significant difference was observed between mindfulness therapy and SPARK perceptual-motor exercises ( $p>0.05)$. Also, the findings related to the follow-up stage showed that the effectiveness of mindfulness and SPARK remained stable $(\mathrm{p}<0.01)$ but the effect of neurofeedback decreased ( $p>0.05$ ).

\section{Conclusion}

This study aimed to compare and determine the effectiveness of therapies based on mindfulness, neurofeedback and perceptual-motor exercises on the difficulty of emotion regulation in children with ADHD. Findings showed that all three interventions were significantly effective in reducing the post-test scores; but in general, mindfulness therapy showed a greater impact compared to other interventions.

These findings are consistent with the results of Roemer et al. (18) and Butler et al. (19) indicating that mindfulness-based intervention can affect emotion regulation. In this regard, it can be stated 
that increased mindfulness in individuals creates an unconditional and balanced state of consciousness that leads to increased clarity and acceptance of physical, mental, behavioral and emotional events in the participants and provides the basis for acceptance of negative emotions and increase of the tolerance that are part of emotion regulation skills (20).

Other findings showed that neurofeedback therapy was effective on the difficulty of emotion regulation in the post-test phase but this effect did not remained stable at the follow-up stage; therefore, these findings coincide with Ghayour Kazemi et al. (25) who showed that neurofeedback therapy was not significantly effective on emotion regulation. In explaining this finding, it can be said that in neurofeedback therapy, focusing on brain waves that are the result of brain function, directly leads to changes in the behavior, thoughts and emotions of the treated people; however, the reduction in the effect can be attributed to the non-repetition of the exercises after the neurofeedback sessions and conditioning of the learned activities in the months after treatment.

Finally, other findings of the study showed that SPARK perceptual-motor exercises reduce the difficulty of emotion regulation in children with ADHD. These findings are consistent with the results of Bishop (29). Overall, it can be stated that participation in the SPARK perceptual-motor activities increases the participants' ability to recognize the patterns of emotion regulation and leads to their emotional discharge; hence, it increases their emotion regulation ability.

Age of the participants and use of parent-based tool were among the limitations of this study and so any generalization of the findings should be made very cautiously. Further research can be focused on performing the above therapies on participants with different age ranges and comparing the results with those of the present study. Also, based on the results, it is suggested that mindfulness and SPARK perceptual-motor exercises can be used as complementary interventions to reduce the symptoms and complications of ADHD in children.

\section{Ethical Considerations}

Compliance with ethical guidelines: Research proposal was approved in Najafabad branch of Islamic Azad University on 12.06.2019, bearing the code of ethics of IR.IAU.NAJAFABAD.REC.1398.119. Participants' parents were assured about the privacy and confidentiality of the research. In addition, written informed consent was obtained from them before entering the study.

Funding: This study was conducted without the support of any organizational or financial institution.

Authors' contribution: This article is extracted from the dissertation of Zahra Bot Shekan, Ph.D. student of general psychology, Najafabad branch, Islamic Azad University. The first author was the senior author, conducting the research, the second and third authors were the supervisors and the fourth and fifth ones were the advisors.

Conflict of interest: There is no conflict of interest in this study.

Acknowledgments: All participants, the supervisors and the advisors are sincerely appreciated. 


\section{مقايسه اثربخشى درمان ذهن آكاهى، نوروفيدبك و درمان مبتنى بر تمرينات ادراكى - حركتى اسپار كى بر دشوارى

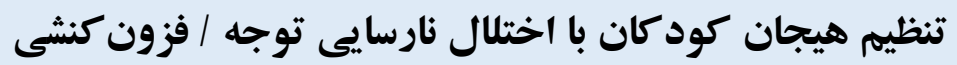

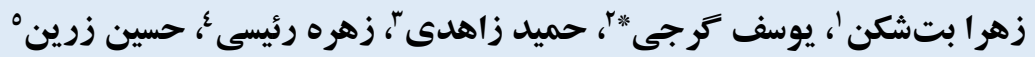

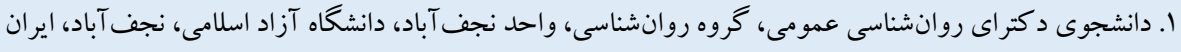

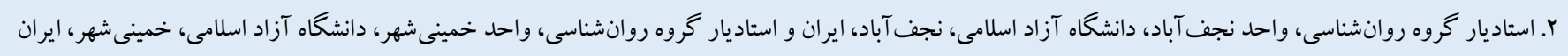

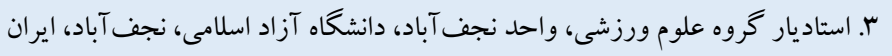

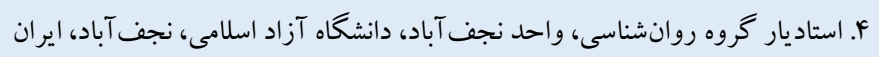

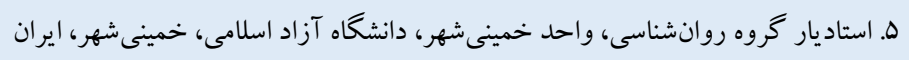

\section{جكيده}

زمينه و هدف: اختلال نارسايى توجه / فزون كنشى يكى از شايع ترين اختلالات عصبى تحولى دوران كودكى است كه بر ابعاد گستردهاى

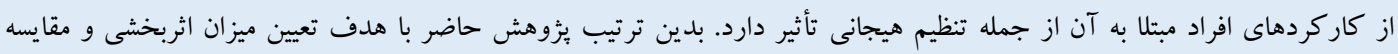

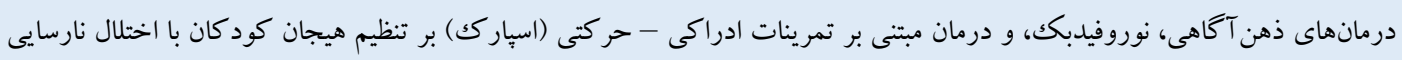
تو جه / فزون كنشى انجام شد.

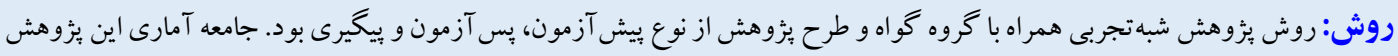

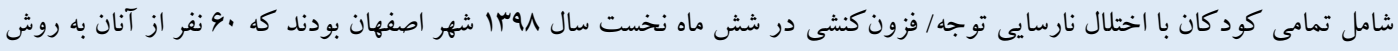

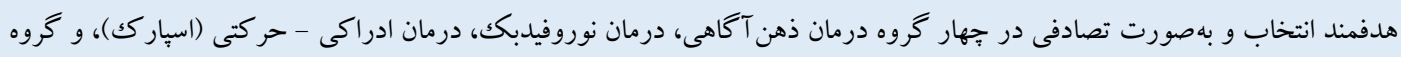

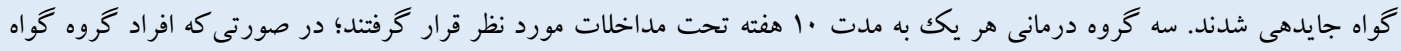

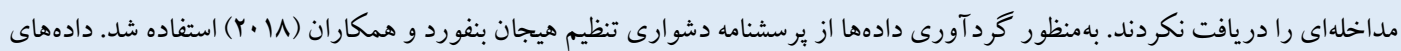

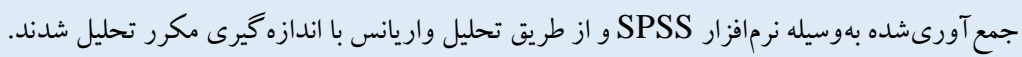

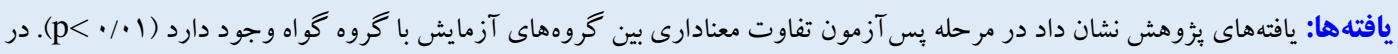

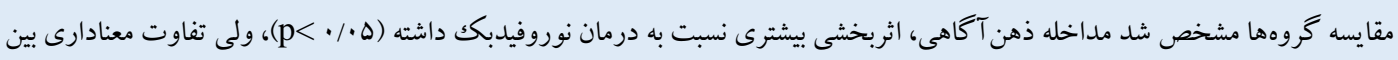

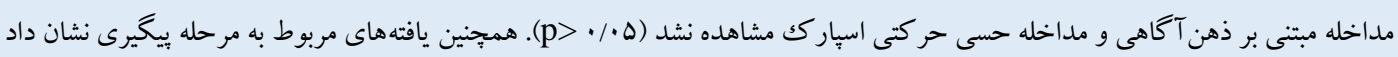

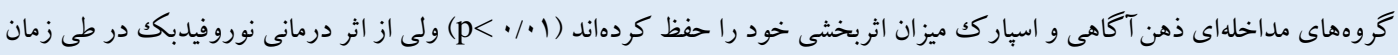

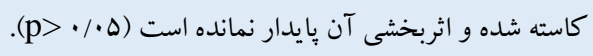

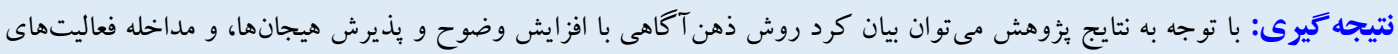

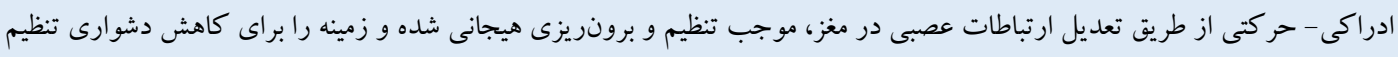

مشخصات مقاله

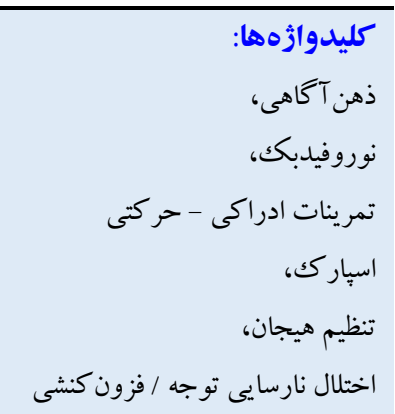

دريافت شده:

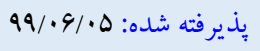

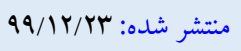

* نويسنده مسئول: يوسف گرجى، استاديار گروه روانشناسى، واحد نجف آباد، دانشكاه آزاد اسلامى، نجف آباد، ايران و استاديار گروه روانشناسى، واحد خمينىهر، دانشكاه آزاد اسلامى، خمينىشهر، ايران.

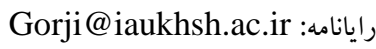

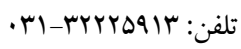


مبتنى بر ذهن آگـاهى ه براى كودكـان اســت (Y) (I). مسداخلـه مبتنى بر ذهن آكَاهى مى توانسـ زنـدكى كودكـان را بـا افزايش تنظيم هيجـان، مهارتهـاى اجتمـاعى، توانـايى در جهـت گيرى توجـه، حـافظـه فعـال؛ حرمت خود V، حس آرامش، و يذّيرش خود به طور مستقيم و قابل توجهى بهبود بخشـد (r) بز بزوهش هاى كسـتردهاى حاكى از مفيد بودن مداخله مبتنى بر ذهن آكَاهى در حيطه هـاى گونـا گون همجيون مديريت تنيدكى (F (1)، اضـطر اب (ه) (1) و ارتقاى مهارت هاى تنظيم هيجان (19) اسـت. در اين راســتا بزوهشهاى كيانى و هاديان فرد (IV)؛ رومئير، ويليسـتون و

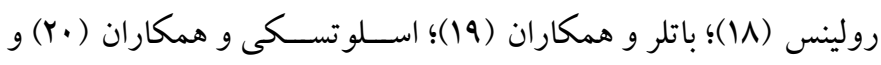
بريتون و همكـاران (YI) نشــان دادهانـد ذهن آكاهى از جمله روشهاى مؤثرى است كه مىتواند در بهبود تنظيم هيجان مورد استفاده قرار كيرد. از ســويى ديخر در بين مداخلههاى غيردارويى براى گروه با اختلال

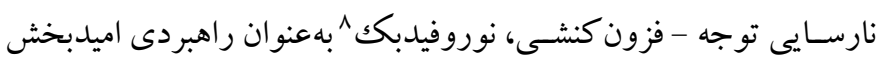
از اوايل دهه ·19V مورد توجه قرار گرفت (YY). ايده اصـلى و يشــتوانه نظرى نوروفيـدبـك بر اين موضــوع اســتوار اســـت كـه فرد از طريق شــرطىسـازى مى تو اند فعاليت هاى مغزى خود را مهار كرده و الكَوهاى نامتعارف فعاليت هاى عصبى - مغزى خويش را هدايت كند. اين الكوهاى نـامتعـارف امواج مغزى، از طريق كـاهش امواج آهســـه (تتا) و افزايش امواج ســريع (بتـا) در كود كان با اختلال نارســايى توجه -فزون كنشــى بهواســطه نوروفيدبكك، به شـكل گيرى امواج بهنجارترى منجر مى شــود

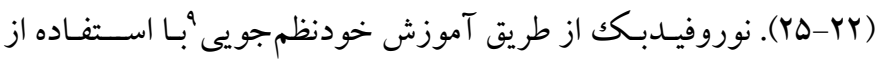
شـيوههاى بر گرفته از روى آورد رفتاردرمانى با هدف قرار دادن الكوهاى نـامتعـارف فعـاليت هاى عصــبى مغزى، مهم ترين عامل براى رســـــن به اهداف خواسته شده است (Yr). از ســوى ديخر يكى از روشهـاى بيشــنهـادى روانيزشــكـان و فيزيولوزيستهاى ورزشـى براى بيشخيرى و درمان اختلالات رفتارى در كود كان و نو جوانان، انجام فعاليتهاى ادراكى - حر كتى اسـت (Y9). در اين زمينه ئزوهش حمايت طلب و همايونى نشان دادند فعاليت بدنى ميزان سـطح انتقالدهندهاى عصبى را در سيستم عصبى مركزى تنظيم مى كند،

6. Working memory

7. Self-esteem

8. Neurofeedback

9. Self-regulation
مقلهم

يكى از شــايع ترين اختلـالـات عصـــى - تحولى دوران كودكى اختلـال نارسـايى توجه - فزون كنشى ' اسـت (1) كه بيش از ينج درصد كود كان

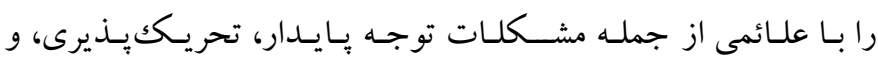
فزون كنشى تحت تأثير قرار مىدهد (Y) و غالباً با اختلالات ديخرى مانند اختلالات خلقى، اضطر ابى، رفتارى، ياد گيرى، و مصرف مواد همراه است (Y). همجينين يُزوهش هاى ديخرى مانند فارائونى و لارسـون نشان دادهاند مبتلايان به اين اختلال، در معرض دامنه وسـيعى از مشـكلات كاركردى از جمله عدم موفقيت در مدرسـه، عدم يذّيرش همسـالان، صـدمات ناشى از تصادفات، رفتار مجرمانه، عدم موفقيت شغلى، طلاق، خود كشى، و مر گك

$$
\text { زودرس قرار دارند (F). (F) }
$$

يـافتـه هاى بزٔوهش هاى انجام شــده نشـــان مى دهد اختلال در تنظيم

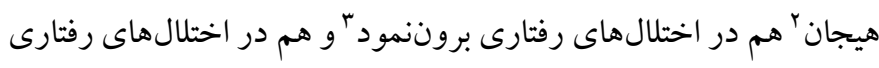
درونتمود كودكان و نوجوانـان نقش دارد (ه) كه در اين ميان مى توان به اختلال نارسـايى توجه - فزون كنشى اشاره كرد (4-4). تنظيم هيجان را مى توان به عنوان فرايند هدفمند جهت هدهى به شــدت، طول مدت و نوع هيجانهاى تجربهشــده تعريف كرد (9). تنظيم هيجانى سـازشنايافته كه

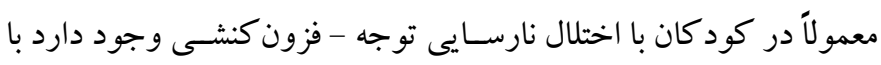
علائم افسـردگىى، علائم اضـطر اب،، علائم اختلال در خوردن، و مشـكلات رفتارى مر تبط بوده است ( •(1). مشكلات تنظيم هيجانات در اين كود كان نيز با مشـكلات اجتماعى مرتبط اسـت؛ اين كود كان معمولاً به دليل اينكه در هنگام عصسبانيت از يرخاشـكرى اسـتفاده مى كنند؛ مشكلات انضباطى در مدرسه و طرد اجتماعى را تجربه مى كنند (ه). در نتيجه شواهدى براى اين ايده به وجود آمده اسـت كه اختلال نارسـايى توجه - فزون كنشـى سـى همبود با مشـكلات در تنظيم هيجان، اختلالات و مشـكلات بيشـترى رادر كودكـان موجب مىشــود كه آن را نيازمند درمانهاى اثربخش مى كند (11). در ســالهـاى اخير درمانكران به اســفتفاده از روى آوردهاى نوين روانشـناختى بر ایى افزايش سـازش يافتكى در كود كان علاقه زيادى نشان دادهانـــ. يكى از جـــيدترين و مؤثرترين شــكل اين نوع درمان، مداخله

1. Attention deficit hyperactivity disorder

2. Emotion regulation

3. Externalizing disorders

4. Internalizing disorders

5. Mindfulness 


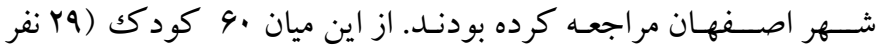
جنسيـت دختر و اسنفر داراى جنسيت يسـر) بر اساس معيارهاى ورود و خروج به صـورت نمونه گيرى هدفمند انتخاب شـده و يس از همتا سازى بر اســاس قرار گرفتن تعـداد جنسـيـت برابر در گروههـا و ميزان و نوع. مصسرف داروهايى كه مصسرف مى كردند، به نسـبت برابر در سـه گروه آزمـايش و يـك كروه كو اه جـايدهى شــدهاند (هر كروه ها كودكك). ملـاكك هـاى ورود و خروج بـه بثزوهش حـاضــر شــامـل عـدم ابتلـا بـه كم توانايى هاى جسـمى و ذهنى، تحصـيل در دوره دوم ابتدايى، دريافت تشـخيص اختلال نارسـايى توجه - فزون كنشـى توســ روانيز شـكـ، رضايت والدين در ورود به يُزوهش، و عدم مصرف داروهاى فلو كستين، رسبريدون، آريبيبرازول، اولونزايين، اسيمديت · r در طى ده هفته مداخله

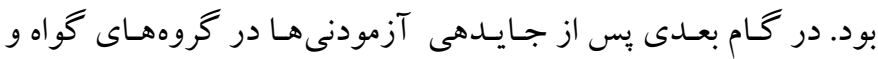

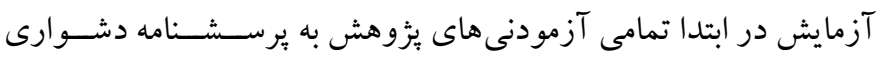

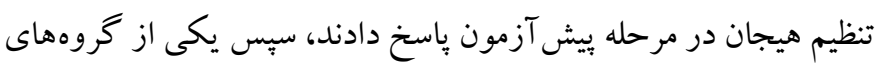
آزمايش، مداخله ذهن آكاهى رادر مدت · ا هفته و هر هفته يكك جلسـه همر اه بـا تمرينـات خـانكى مر تبط بـا ذهن آكَاهى درايفت كردند. كروه آزمايش دوم تمرين هاى ادراكى حر كتى اسـهِارك را به مدت · ل1 هفته و

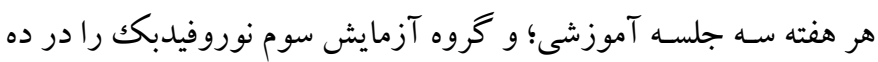
هفتـه و هر هفتـه F جلســه دريافت كردند. در طى اين مدت افراد گروه كواه مـداخلـهاى دريـافت نكردنــد و در يـايان جلســات درمانى، تمامى آزمودنى هاى بززوهش (آزمايش و گواه) مجدداً به برسـشــنامه دشــوارى

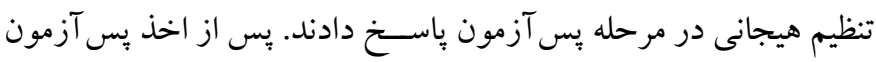
براى اطلـاع از ميزان ماند كارى ميز ان تأثير درمانهاى اجراشـــه، يس از

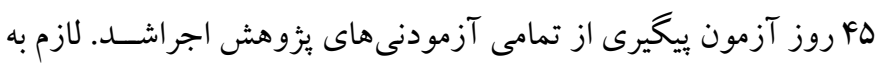
ذكر اســت كـه گروه گواه در طى مـدت زمان ئزوهش در انتظار درمان

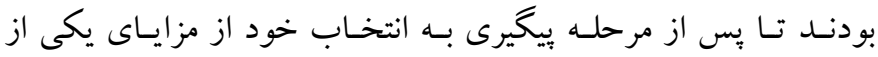
روش هاى درمانى بهرهمند شوند.

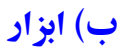
برسـشـامه دشـولرى تنظيم هيجان بنغورد و همكاران" ': اين برسـشنامه در

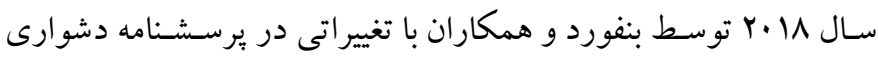

ولى در مقايسـه با بز وهش هاى متعدد درباره مداخلات دارويى، مطالعات اندكى درباره تأثير فعاليتهاى ورزشـى در كود كان انجام شــده اســت (YV) (Yمجنين يافتهاى يثوهش جن نيز مؤيد نتايج ضدونقيض اثربخشى فعاليتهاى ورزشى بر اختلالات رفتارى كود كان و نارسـايى همراه با آن اسـت (YN)؛ با اين وجود يافته هاى بزٔوهش بيشـوب نشـان داد تمرينهاى ادراكى حر كتى اسـيار كَ'، مداخله آموزشـى مؤثرى براى تنظيم هيجان

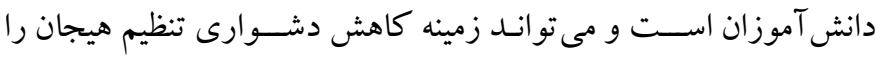

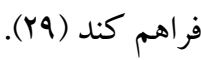
بـا توجسه بـهـ ئزوهشهاى انجام شــــه در زمينه درمان افراد با اختلال نارسـايى توجه - فزون كنشسى مى توان بيان كرد، تعداد نسـبتاً كمى از اين افراد، درمـانى مناســب با اختلال خود و دشــــارى تنظيم هيجان دريافت مى كنــــ كـه در بســــارى از موارد با يايدار نبودن اثرات درمانى روبهرو مىشوند (·r). همجِنين جِندين مداخله مؤثر دارويى، شناختى، و رفتارى هم اكنون براى درمان اختلال نارســيـى توجه - فزون كنشـى وجود دارند (اسM (M) كه نشـانه هاى مركزى اين اختلال را هدف قرار مىدهند (TM) ولى كمتر بر مســائسل جـانبى همر اه بـا اين اختلال مانند دشـــوارى تنظيم هيجان تمركز مى كنند؛ بنابراين، استفاده از مداخلهاى كه تأثير خود رادر زندكى فرد حفظ كند، بسيار اهميت دارد. بدين ترتيب بثوهش حاضر با هـدف تعيين ميزان اثربخشــى و مقـايســه مداخله مبتنى بر ذهن آكاهى، نوروفيـدبك، و تمرينات ادراكى - حر كتى (اســياركك) بر تنظيم هيجان كود كان دوره دوم ابتدايى با اختلال نارسـايى توجه ـــزوون كنشى انجام شد.

روش

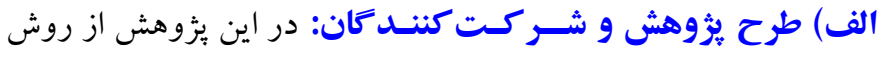

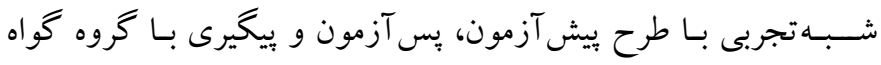

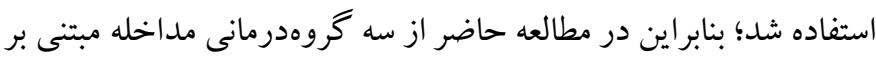

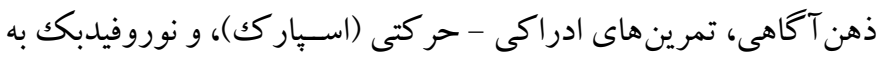

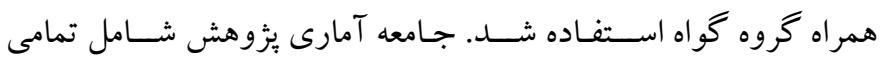

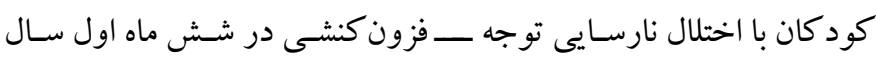

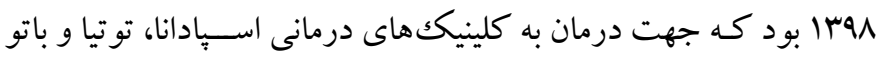


يس از ترجمه در اختيار اسـتاد راهنما و جهار متخصـص حوزه كودك قرار گرفت كه روايى محتوايى آن با استفاده از روش لاشه بr/ • محاسبه

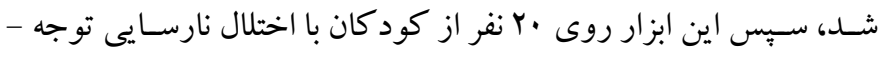
فزون كنشـى اجرا شــده و با روش آلفاى كرونباخ، همسـانى درونى آن محاسـبه شد كه براى كل برسشنامه MM/ • و در خردهمقياس هاى آن 199 •

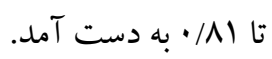

ج) بر نامه مداخله ا. مد/خله مبتنى برتمرينات ادراكسى حركتى اسيارك: برنامه مداخله مربوط بـه يكى از گروههـاى آزمايش، مداخله مبتنى بر تمرينات ادراكى

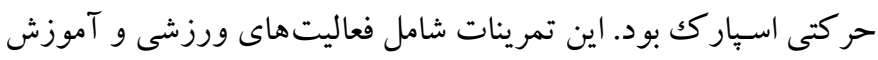

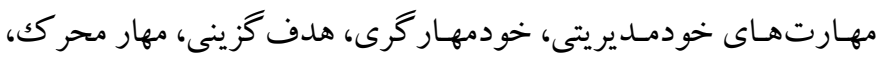
خودتشويقى، خود آموزى، و حل مسئله با روش ورزشهاى سركرم كننده و حر كات هدفمند در قالب بازى در ايستخاههاى مختلف بوده است و به صسورت هفتهاى سـه جلسـه و هر جلسه ·ودقيقه (ه دقيقه تعويض لباس، •ا دقيقه كرم كردن و حر كات كشـشـى، ·f دقيقه سـه دسـته حر كات اسـتوارى مربوط به تعادل، جابهجايى مربوط به كل بدن، اندام و دسـتويا و حر كات دست كارى، و ه دقيقه سـرد كردن) اجرا شد (ها). در جدول ا، جارجوب جلسات اين برنامه مداخلهاى كزارش شده است.
تنظيم هيجان گراتز و رومر 'به فرم ياسـخدهى والدين تبديل شد و هدف آن ســجش ميزان دشـوارى تنظيم هيجان در كود كان با اختلال نارسـايى توجه - فزون كنشـى اسـت. برسـشـنامه دشـوارى تنظيم هيجان داراى بو كويه و 9 عامل عدم يذيرش يّاسخهاى هيجانى بَ، دشوارى در انجام رفتار هدفمند"، دشـوارى در مهار تكانه ب، فقدان آكاهى هيجانى هُ دسـترسـى محدود به راهبردهاى نظمبخشسى هيجانى و' و عدم وضسوح هيجانى ل بر اسـاس طيف ليكرت هد درجهاى است (MF). دامنه نمرات قابل دريافت در اين يرسـشنامه وس تا •11 بوده كه نمرات بالاتر نشاندهنده اختلالات بيشتر درباره تنظيم هيجان اســت. در يزٔوهش بنفورد و همكاران در كود كان با اختلـال نـارســايى توجـه - فزون كنشــى، روايى و اعتبـار اين ابزار مورد ارزيابى و تأييد قراركرفته اسـت. يافته هاى يزووهش آنها نشان دادند اعتبار

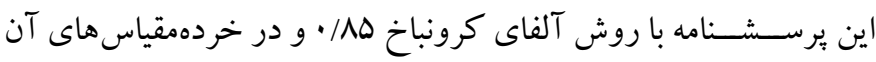

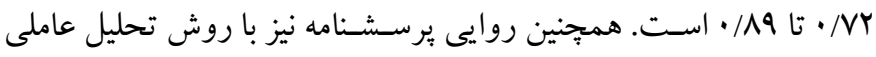
تأييدى مورد بررسـى قراركرفته و نشـان داد تمام مؤلفه هاى برسـشــنامه

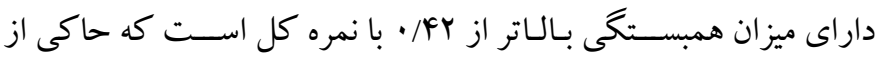
مناسـب بودن آن جهت اسـتفاده در بزوهش اسـت (MF). با توجه به اينكه برسشنامه حاضر تاكنون در ايران ترجمه نشده و اطلاعى از ميزان روايى و اعتبار آن در جامعه فارسىزبان وجود ندارد؛ در اين مطالعه اين برسشنامه

جدول 1: جهارجوب جلسات درمان كروهى اسيار كى براى كود كان با اختلال نارسايى توجه- فزون كنشى مك كنزى و همكاران (به نقل از جم)

\begin{tabular}{|c|c|c|c|}
\hline سوم & دوم & يكم & \\
\hline تمرينات ايستكاهى & بازىهاى گروهى & ايروبيك كود كان & يكم \\
\hline ايروبيك كود كان & تمرينات ايستگاهى & بازىهاى گروهى & دوم \\
\hline تمرينات ايستكاهى & ايروبيك كود كان & تمرينات ايستگاهى & سوم \\
\hline ايروبيكك كود كان & تمرينات ايستگاهى & بازىهاى گروهى & جهارم \\
\hline بازىهاى گروهى & تمرينات ايستگاهى & ايروبيك كود كان & ينجم \\
\hline بازىهاى گروهى & ايروبيك كود كان & تمرينات ايستگاهى & 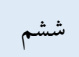 \\
\hline تمرينات ايستگاهى & ايروبيك كود كان & بازىهاى گروهى & هفتم \\
\hline تمرينات ايستگاهى & بازىهاى گروهى & ايروبيك كود كان & هشتم \\
\hline تمرينات ايستگاهى & ايروبيكك كود كان & تمرينات ايستگاهى & نهم \\
\hline بازىهاى گروهى & تمرينات ايستكاهى & ايروبيك كود كان & دهم \\
\hline
\end{tabular}

5. Lack of emotion awareness

6. Limited access to emotion regulation strategies

7. Lack of emotional clarity
1. Gratz \& Roemer

2. Non-acceptance of emotional responses

3. Difficulties engaging in goal-directed behaviors

4. Impulse control difficulties 


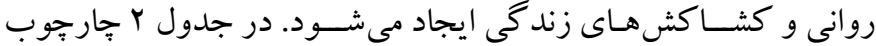
جلسـات مداخله مبتنى بر ذهن آكاهى در · ا جلسـه يككسـاعته بر اسـاس بسته درمانى بورديك ارائه شده است (r).

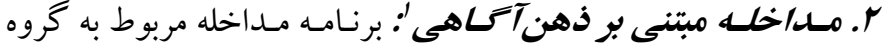
آزمايش دوم، مداخله مبتنى بر ذهن آكاهى بود. ذهن آكاهى مانند ســاير مهارتها، به تمرين نياز دارد؛ در نتيجه به نظر مىرســـ اكر آموزش اين مهارت از سـنين كودكى آغاز شـود، نوعى ايمنسازى در بر ابر فشارهاى

جدول r: جهار جوب جلسات درمان كروهى مداخله مبتنى بر ذهن آكاهى براى كودكان با اختلال نارسايى توجه ـ فزون كنشى بر اساس بسته درمانى بورديك (r ا )

شرح جلسه

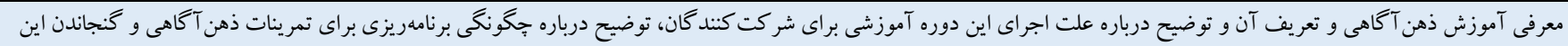

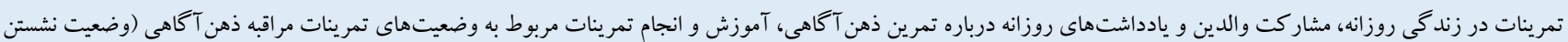

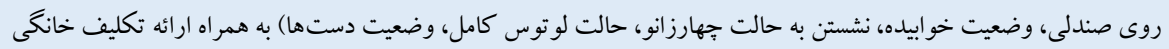

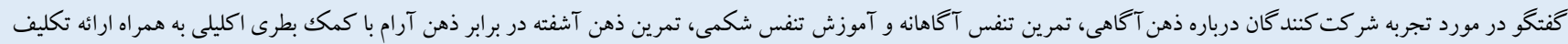
خانگیى

كفتكو درباره تجربه شر كت كندگان از ذهن آكاهى و تكرار تنفس ذهن آكاهانه و آموزش اسكن بدن. آموزش آكاهى نسبت به زمان حال با كمك تمرين ليوان آب، به همراه ارائه تكليف خانكى

تكرار تمرينات بايه تنفسى (تمرين تنفس آرميدگى مقدماتى) و انجام حر كات ذهن آكاهانه به همر اه ارائه تكليف خانكى

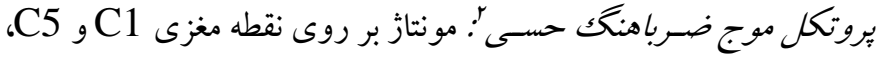

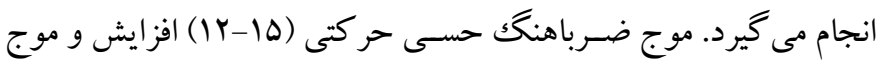

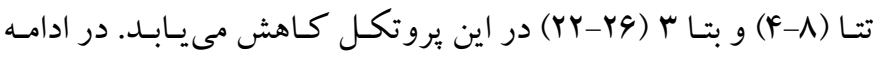
ساختار جلسات ارائهشه در جدول سارائه شده است.
"ا. مداخله نوروفيدبك: برنامه مداخله مربوط به گروه آزمايش ســوم)،

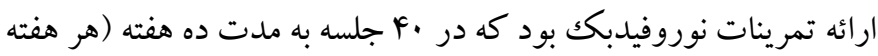

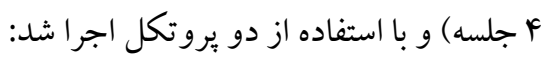

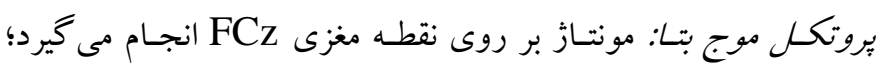

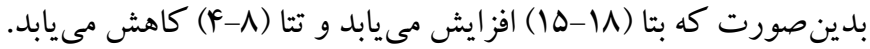

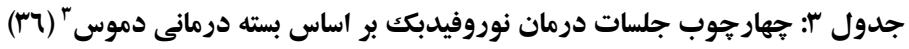

\begin{tabular}{|c|c|c|c|c|}
\hline جهارم & سوم & 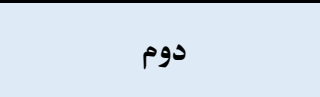 & يكم & هفتسه \\
\hline آموزش ضرباهنك حسى حر كتى & آموزش بتا & آموزش ضرباهنك حسى حر كتى & آموزش بتا & يكم \\
\hline آموزش ضرباهنك حسى حر كتى & آموزش بتا & آموزش ضرباهنك حسى حر كتى & آموزش بتا & 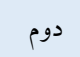 \\
\hline آموزش ضرباهنك حسى حر كتى & آموزش بتا & آموزش ضرباهنك حسى حر كتى & آموزش بتا & 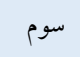 \\
\hline آموزش ضرباهنك حسى حركتى & آموزش بتا & آموزش ضرباهنك حسى حركتى & آموزش بتا & 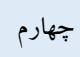 \\
\hline آموزش ضرباهنك حسى حركتى & آموزش بتا & آموزش ضرباهنك حسى حر كتى & آموزش بتا & ينجم \\
\hline آموزش ضرباهنك حسى حر كتى & آموزش بتا & آموزش ضرباهنك حسى حركتى & آموزش بتا & ششم \\
\hline
\end{tabular}

3. Demos

1. Mindfulness intervention

2. Sensory motor rhythm 


\begin{tabular}{|c|c|c|c|c|}
\hline آموزش ضرباهنك حسى حر كتى & آموزش بتا & آموزش ضرباهنك حسى حر كتى & آموزش بتا & هفتم \\
\hline آموزش ضرباهنك حسى حر كتى & آموزش بتا & آموزش ضرباهنگك حسى حر كتى & آموزش بتا & هشتم \\
\hline آموزش ضرباهنك حسى حر كتى & آموزش بتا & آموزش ضرباهنگك حسى حر كتى & آموزش بتا & نهم \\
\hline آموزش ضرباهنك حسى حر كتى & آموزش بتا & آموزش ضرباهنكَ حسى حر كتى & آموزش بتا & دهم \\
\hline
\end{tabular}

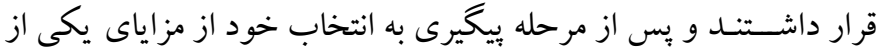

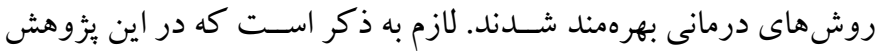
براى تحليل دادهها از روش اندازه كيرى مكرر اسـتفاده شــــ و دادهها در

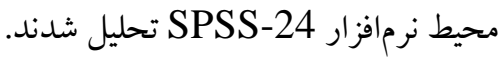

يافتهها در جدول \& ميانكين و انحراف معيار ميزان دشوارى تنظيم هيجان سـه وضعيت بيش آزمون، پِ آزمون، و ييخيرى گزارش شده است.
روش اجرا: براى اجراى اين مطالعه ابتدا مجوزهاى للازم از دانشگاه آزاد

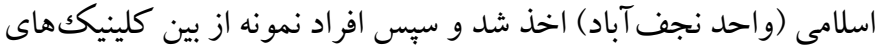

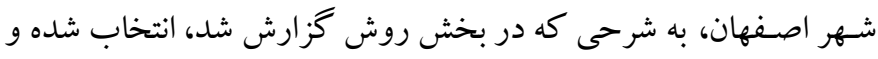

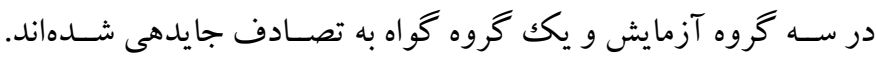

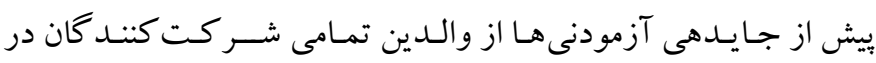

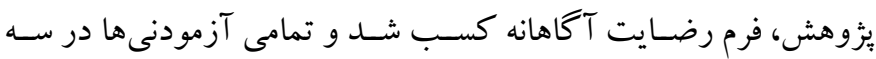

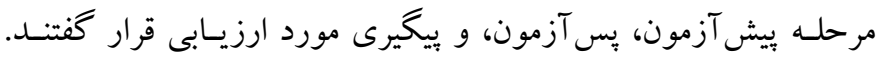

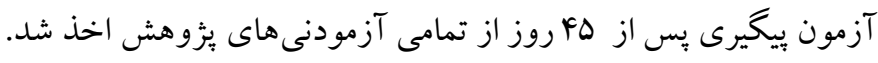

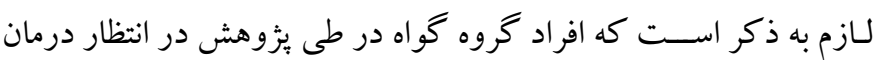

جدول ع: ميانكين و انحر اف استاندارد دشوارى تنظيم هيجان به تفكيك كروههاى ثئوهش

\begin{tabular}{|c|c|c|c|c|c|c|c|c|c|c|}
\hline \multicolumn{2}{|c|}{ تفاوت } & \multicolumn{2}{|c|}{ اسيار كى } & \multicolumn{2}{|c|}{ نوروفيدبك } & \multicolumn{2}{|c|}{ ذهن آكاهى } & \multicolumn{2}{|c|}{ كواه } & \\
\hline معنادارى سطح & Tماره F & استاندارد اف اف & ميانكين & استاندارد اف اف & ميانكين & استاندارد اف اف & ميانكين & استاندار & ميانكين & \\
\hline$\cdot 109$ & .199 & $\Lambda / v$ & $111 / 9$. & V/AV & $|r| / 9 V$ & $V / 91$ & $\mid Y Y / 9 V$ & $9 / \% 4$ & $\mid r Y / \cdot V$ & ييش آزمون \\
\hline.$/ \cdot 1$ & $r Y / \cdot q$ & $V / Y F$ & $1.9 / 0 r$ & G/VD & $\| r / \cdot V$ & $\Delta / r$. & $1 . r / 9$. & $V / 9 \Lambda$ & $|Y| / A V$ & يس آزمون \\
\hline.$/ \cdots 1$ & $1 \cdot / \Delta V$ & $V / 91$ & 1.V/Ir & $\Lambda / V V$ & $\| 1 \% / \cdot v$ & $f / v$. & $1.9 / \pi r$ & $\Lambda / \wedge)$ & $1 r \cdot \%$ & بيخيرى \\
\hline
\end{tabular}

به دست آمده تأييد شد (ه./p>). نتايج بهدست آمده از آزمون لوين نيز

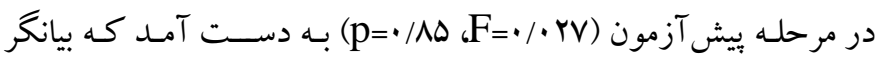

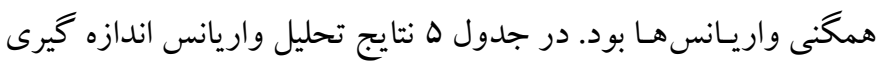

$$
\text { مكرر گزارش شده است. }
$$

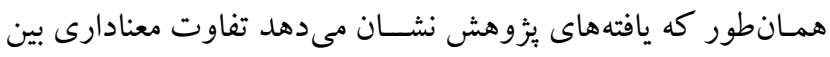

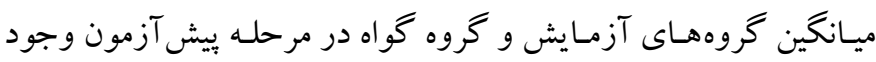

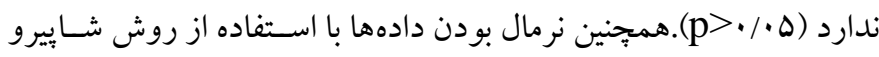

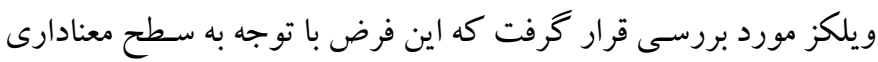

جدول 0: نتايج تحليل واريانس اندازهَيرى مكرر براى دشوارى در تنظيم هيجان

\begin{tabular}{|c|c|c|c|c|c|c|c|}
\hline توان آزمون & مجذور سهمى اتا & سطح معنى دارى & F T T F F & ميانغين مجذورات & درجه آزادى & مجموع مجذورات & منبع تغيير \\
\hline $1 / \cdots$ & - /AgF & $.1 \cdots 1$ & $19 / 1 \mathrm{M}$ & $11 \mathrm{VI/9FA}$ & $r$ & rDID/AFF & عامل بين گروهى \\
\hline $1 / \cdot$ & $\cdot / 4 \cdot \Delta$ &.$/ \cdots 1$ & $\mathrm{rN} / \mathrm{FV}$ & I9MN/NIV & r & raW/9rr & اثر عامل \\
\hline . /994 & $\cdot / Y \backslash \Lambda$ & $\cdot / \cdots 1$ & D/rIT & rVT/OY. & 9 & IGro/Irr & تعامل اثر عامل ×گروه \\
\hline
\end{tabular}

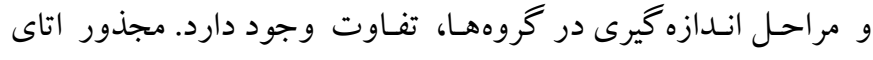

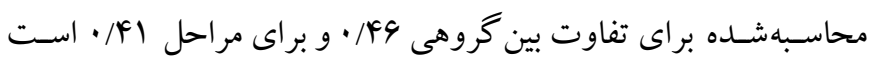

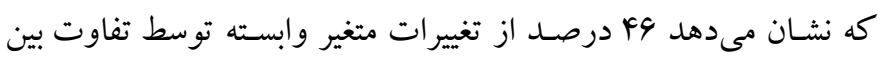

همانطور كه در جدول هـ نشان دادهــــ اسـت، ميزان F محاسبه

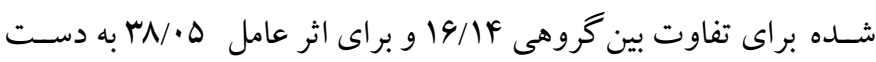

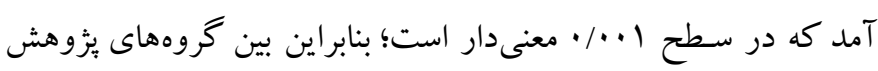


گروههاى درمانى، و أFروصسد توسـط زمان اندازهگيرى، قابل تبيين

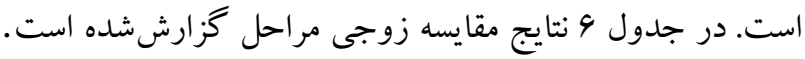

جدول 7: نتايج آزمون بونفرونى براى مقايسه كروهى در دشوارى در تنظيم هيجان در مراحل بس آزمون و بيعيرى

\begin{tabular}{|c|c|c|c|c|c|}
\hline سطح معنادارى & خطاى استاندارد & A-B اختلاف ميانكين & مرحله B & مرحلهA & مرحله \\
\hline$\% / \cdot 1$ & $1 / 4 \Delta$ & $9 / 19$ & ذهن آكَاهى & كواه & \multirow{6}{*}{ يس آزمون } \\
\hline$\% \cdot 1$ & $1 / F \Delta$ & $1 \% / 11$ & نوروفيدبك & كواه & \\
\hline$\%$ & $1 / 4 \Delta$ & $9 / 11$ & اسباركك & كواه & \\
\hline$\% \cdot 1$ & $r / F F$ & $-9 / 99$ & نوروفيدبكك & ذهن آكاهى & \\
\hline ( & $r / F A$ & $-F / A F$ & اسيارك ك & ذهن آكَاهى & \\
\hline - MrYF & $r / 49$ & $f / \wedge \Delta$ & اسِار كs & نوروفيدبك & \\
\hline$\% \cdot \cdot 1$ & r/AY & $15 / 99$ & ذهن آكاهى & كواه & \multirow{6}{*}{ ييخيرى } \\
\hline D T TFY & r/AY & $\Delta / Q Y$ & نوروفيدبك & كواه & \\
\hline.$\cdot \cdot 1$ & $r / \wedge \Delta$ & IT/VQ & 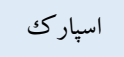 & كواه & \\
\hline.$/ 4 \Lambda$ & r/Ar & $-V / V V$ & نوروفيدبك & ذهن آكاهى & \\
\hline $1 / \cdot$ & r/A9 & $-\bullet / 94$ & اسبارك & ذهن آكاهى & \\
\hline.$/ 119$ & Y/AF & G/A & اسيار كs & نوروفيدبكك & \\
\hline
\end{tabular}

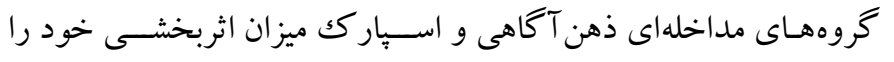

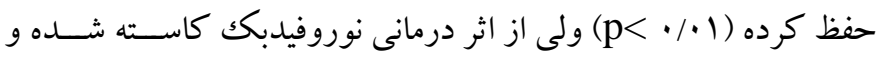

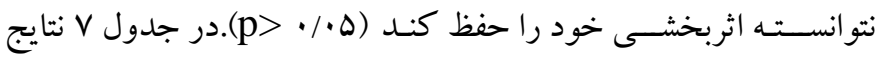
آزمون بونفرونى براى مقايسـه آزمون و عضويت گروهى درو در دشوارى در تنظيم هيجان گزارش شده است.
بـا توجـه به نتايج جدول و ودر مرحله يس آزمون تفاوت معنادارى بين

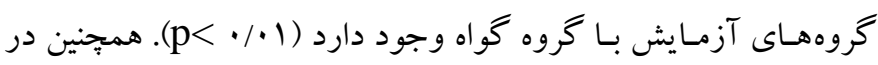
مقايسه كروهها مشخص شد مداخله ذهن آكاهى اثربخشى بيشترى نسبت

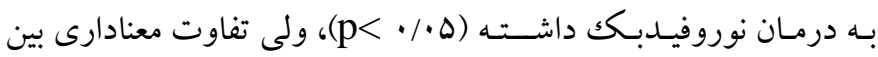
مداخله مبتنى بر ذهن كاهى و مداخله حسى حر كتى اسـيار كك مشـاهده

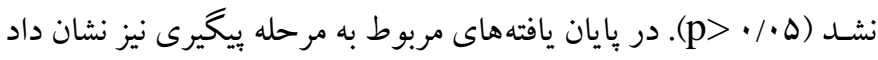

جدول \: نتايج آزمون بونفرونى براى مقايسه آزمون و عضويت تروهى در دشوارى در تنظيم هيجان

\begin{tabular}{|c|c|c|c|c|c|}
\hline سطح معنادارى & خطاى استاندارد & A-B اختلاف ميانكين & مرحله B & مرحلهA & نوع مقايسه \\
\hline$\cdot 1 \cdot \cdot 1$ & $1 / \wedge 1$. & 1./1Tr & يس آزمون & ي بيش آزمون & \\
\hline.$/ \cdots 1$ & $1 / 9 \cdot Y$ & $9 /{ }^{\prime} \cdot$ & يِيَيرى & & ذهن آ گاهى \\
\hline $1 / \cdot \cdot$ & $1 / 941$ & - - - ब & ييخيرى & يس آزمون & \\
\hline.$/ . \mathrm{rq}$ & $1 / v 9 \Delta$ & $r / q .$. & پِ آزمون & ش & \\
\hline$. / 1 . r$ & r/IVD & F/FAT & ييگيرى & يَيس رمون & نوروفيدبك \\
\hline $1 / \cdot$ & $1 / \wedge 9 \wedge$ & $-.1 .9 \mathrm{~V}$ & بيخيرى & يس آزمون & \\
\hline$\% \Delta$ & $1 / W r$ & 9/1m & يس آزمون & بث آزمدذ & \\
\hline.$/ \cdot 1$ & $r / 1 \cdot 1$ & 9/VGV & ييكيرى & 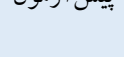 & اسهيار ك \\
\hline $1 / \cdot \cdot$ & r/MAQ & $.19 \pi$ & بيخيرى & بس آزمون & \\
\hline
\end{tabular}

درمان نوروفيدبكك تنها بر نمرات پِ آزمون دشـوارى تنظيم هيجان تأثير

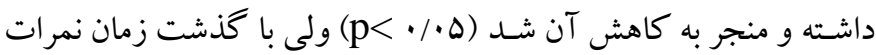

يافتهاى بزووهش نشــان داد در مداخله مبتنى بر ذهن آكاهى نمرات

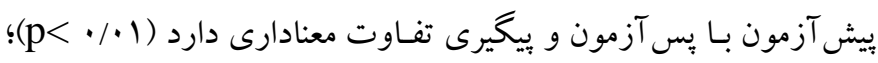


فراهم مى كنـد ( •Y). علـاوه بر اين زمـانى كه افراد در درمان ذهن آكاهى شــركت مى كنند، با بالا رفتن اين مهارت، آنها دانش و بينش عميق ترى نسـبت به فر ايندهاى شـناختى و توانمندى هاى خود به دسـت مى آورند و مى توانــد در برخورد بـا تكاليف، نســبت به خود، ديكران و هيجانات و موقعيتها در زمان حال، تأثير مثبتى بر مشكلات تنظيم هيجان خود داشته باشــد (Y). در مجموع مى توان ادعا كرد كه كود كان با اختلال نارسـايى توجه - فزون كنشـى كه در مداخله مبتنى بر ذهن آكاهى قرار كرفتهاند، توانايى بالاترى در بهبود دشوارىهاى هيجانى خود نشان دادند. در مجموع بر اســاس يـافتـههـاى اين مطـالعـه، مـداخلـه مبتنى بر ذهن آكاهى به بهبود وضسعيت هيجانى آزمودنى هاى بزٔوهش منجر شـده اســت. مـداخلـه مبتنى بر ذهن آكَاهى بـه حـالـت بردازش مهارشــــه و هوشـيارانهاى اطلاق مىشـود كه متضاد بى توجهى است. زيربناى اين نوع مداخله بر اسـاس بذيرش حالات هيجانى و افكار ناخوشـايند شكل كرفته اسـت كه موجب افزايش توانمندى فرد در مهار افكار و هيجانات شـده و موجب مى شـود كه فرد بدون تجربه آشفتكى هيجانى در ذهن خويشتن، دامنـه وســيعى از افكار و هيجانات را مورد وارسـى قرار دهد. همجيجين مى توان بيـان كرد مــاخلـه مبتنى بر ذهن آكَاهى تكنيـك هـايى را به كار مىبرد تا ديد گاه فرد در مورد مفيد بودن شــيوههاى رويارويى با افكار و هيجانات تغيير داده و به ســمت تجربه اصــلاح هيجانات ناخوشـايند و يــذيرش آنهـا ســوق داده شـــود؛ در نتيجـهـ آزمودنى در كنـار آمـدن بـا هيجـاناتش، احســاس خودمهار گرى و تســلط و در نهايت خود تنظيمى هيجانى بيشـترى خواهد داشت؛ بدين ترتيب مىتوان نتيجه گرفت كه در ذهن آكاهى، افراد به وسيله آكَاهى هايى كه از هيجانات خويش به دست مى آورنـد ســعى بـه تنظيم مجدد هيجانهاى خود كرده كه اين توانايى، موجبات تنظيم هيجانى را در آنها فراهم مى آورد. يافتهاى ديخر اين بثزوهش نشـان داد درمان نوروفيدبك بر دشوارى تنظيم هيجـان تـأثير دارد. اين يـافتـه بـا نتـايج يثزوهش غيور كـاظمى و

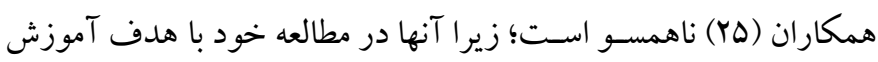
نوروفيـدبـك بر نظم جويى هيجـان و فعـاليـت امواج مغزى بـا روش تكك آزمودنى نتيجـه كرفتنـد كـه درمـان نوروفيـدبـك بر تنظيم هيجـان آزمودنى هاى بثوهش معنادار نبوده است. در تبيين اثربخشى نوروفيدبك بر دشوارى تنظيم هيجان كود كان با اختلال نارسايى توجه ـ- فزون كنشى
دشـــوارى تنظيم هيجـان افزايش داشــــه و اين درمان تأثير ماند كارى بر دشـوارى تنظيم هيجان از خود نشـان نداد (ه •/ > p). همجنين در درمان

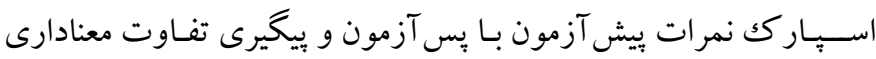
دارد و نمرات بس آزمون در مرحلـهى بيخيرى كـاهشيـافتـه و اثر دوره مداخله مبتنى بر ذهن آكاهى بر دشـوارى تنظيم هيجان ثابت مانده اسـت

$(\mathrm{p}<\cdot 1 \cdot 1)$

\section{بحث و نتيجه تيرى}

يثزوهش حاضر با هدف تعيين اثربخشى و مقايسه درمانهاى مداخله مبتنى

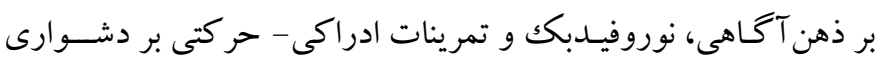
تنظيم هيجان كود كان با اختلال نارسايى توجه ـ- فزون كنشى توجه انجام شـــد. يافته هاى يزٔوهش نشـــان دادند هر ســهـ درمان تو انســتند تغييرات معنـادارى در كـاهش نمرات آزمودنى هاى يثزوهش در مرحله يس آزمون ايجـاد كنـــ (ه •/p)، ولى در مرحلـه بيخيرى فقط مـداخلـه مبتنى بر ذهن آكَاهى و اســار كك اثربخشسى خود را حفظ كردند (1 • • p) و از ميز ان اثربخشى درمان نوروفيدبكك كاسته شده بود (ه • • p>). همجنين ديخر يافته هاى اين بثزوهش نشــان داد ميزان اثربخشـى مداخله مبتنى بر ذهن آكاهى و اسـيارك نسـبت به درمان نوروفيدبكك بر دشـوارى تنظيم

$$
\text { هيجان بيشتر بود (ه) ( • (p). }
$$

اين يافتها با نتايج حاصـل از يزوهش هاى كيانى و هاديان فرد مبنى بر اثربخشـى درمـان مبتنى بر ذهن آكَاهى در بهبود بىنظمى هيجـانى نوجوانان با اختلال نارسـايى توجه - فزون كنشى (IV)؛ رومئير و همكاران مبنى بر تأثير مثبت مداخله مبتنى بر ذهن آكاهى بر تنظيم هيجان (1N)؛ و مطـالعـه بـاتلر و همكاران مبنى بر اثربخشـى درمان ذهن آكاهى مبتنى بر كاهش تنيدگى بر دشـوارى تنظيم هيجان و بهبود وضوح عاطفى هيجانى و توجـه بـه هيجـانات، (19) همســو اســت. در تبيين اثربخشــى درمان ذهن آكاهى بر دشـوارى تنظيم هيجانى كود كان بالختلال نارسايى توجه فزون كنشى بايد بيان كرد كه با افزايش ذهن آكاهى، در افر اد حالت بدون قضــاوت و متعادلى از آكاهى ايجاد مى شـــود كه به افزايش وضــوح و يـــيرش هيجانها، رخدادهاى فيزيكى، ذهنى، رفتارى و احســاسـى در آزمودنى هاى بزوهش منجر مىشـود و زمينه را براى بروز يذيرش هيجان منفى و افزايش تحمـل كـه جزئى از مهارت هـاى تنظيم هيجانى اســت، 
شــناختى در افراد شـــده، و تحول شــناختى به بهبود تو انايى هاى فرد در تنظيم هيجانى منجر مىشود؛ به عبارتى تحول مهارت هاى تنظيم هيجانى،

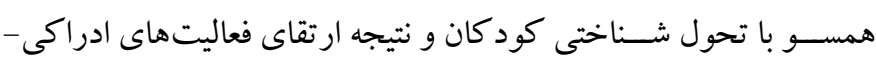
حر كتى ايشان است. در اين مطالعه افر اد نمونه به صسورت در دسـترس انتخاب شـدهاند و همجينين از يرسـشـامه والدمحور براى جمع آورى دادهها و ارزيابى سطح دشـــوارى هيجـانى كو كان اســتفاده شــــ در نتيجه در تعميم يافته هاى يثزوهش بايد با احتياط عمل كرد. ييشـنهاد مىشـود در يزوهشهاى آتى ضـمن اسـتفاده از روشهاى نمونه گيرى تصـادفى، از شـيوههاى مختلف ارزيابى كودك مانند مشـاهده و مصـاحبه بالينى استفاده كرد. همجيجنين بر اســاس يافته هاى بثزوهش حاضــر مبنى بر ميزان اثربخشـى و ماندكارى مـداخله مبتنى بر ذهن آكاهى و تمرينات ادراكى - حر كتى اســـار كك بر دشـوارى تنظيم هيجان كود كان بيشـنهاد مى شـود اين دو شسيوه درمان به عنو ان مـداخلـههـاى تكميلى جهـت كـاهش نشــانـها و عوارض اختلال نارسـايى توجه - فزون كنشـى در كلينيككهاى روانشـناختى و مدارس آموزش عمومى و خاص توســ روانيزشـكان و روانشــنـــــان حيطه كودكى، استفاده شود.

\section{ملاحظات اخلاقى} ييروى از اصــول اخلـاق يزوهش: طرح ييشـــهـادى اين يثوهش در تـاريخ

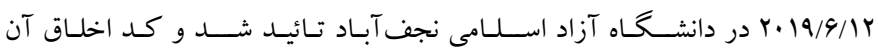
IR.IAU.NAJAFABAD.REC.1398.119 است. به والدين شر كت كنند گان درباره رعايت حريم خصـوصى و حفظ اطلاعات شخصى فرزندشان اطمينان داده شد و قبل از ورود به مطالعه، رضايت آكاهانه و كتبى از آنها اخذ شد. حامى مالى: اين مطالعه بدون حمايت نهاد سازمانى و مالى انجامشده است. نقش هر يكك از نويسـند كان: اين مقاله بر گرفته از رساله دكتراى زهر ابتشكن در رشـته روانشـناسـى عمومى دانشـاه آزاد نجف آباد اسـت. نويسـنده نخسـت به عنوان مجرى طرح و نويســنده اصسلى، نو يســد گان دوم و ســوم بهعنوان اسـتادان راهنما، و نويسند كان جهارم و ينجم بهعنوان استادان مشاور در اين مطالعه نقش داشتند. تضاد منافع: نو يسند كان اعلام كردند هيج تضادى در منافع وجود ندارد. تشكر و قدردانى: بدين وسـيله از تمامى افراد شركت كننده در اين مطالعه و همجنين استادان راهنما و مشاور اين مطالعه تشكر و قدردانى مىشود.
در اين مطالعه بايد توجه داشت كه درروش درمانى نوروفيدبك با تمركز بر امواج مغزى كه حاصـل عملكرد مغز بوده، به طور مسـتقيم به تغيير اتى

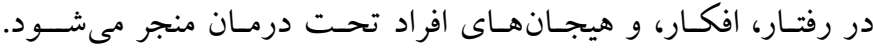
نوروفيدبك با اســفاده از تكنيكك بازخورد فعاليت هاى الكتريكى مغز و شـرطىسـازى عامل، به آزمودنى مى آموزد كه مىتواند الكوهاى آشـفته

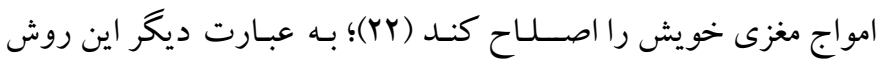
درمانى با استفاده از شرطى سازى عاملى، باعث افزايش موج بتا و كاهش فراوانى موج تتا در افراد با اختلال نارسـايى توجه ـــزون كنشى مى شود (Yr). در هر صــورت بـا توجه به نتايج يزوهش هاى انجام شـــده، ميزان اثربخشى اين درمان با كذشـت زمان، كاهش مى يابد (1) كه از اين نظر با يافته هاى بثوهش حاضـر همسـو و همراسـتا بوده اسـت كه دليل آن را مى توان به دلايلى مانند عدم تكرار تمرينهاى ارائهشـده يس از جلســات

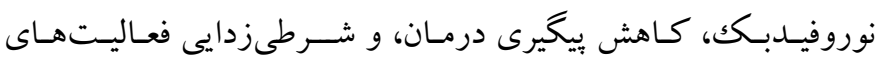
آموختهشده در ماههاى يس از درمان نسبت داد. ديخر يافته اين يزٔوهش نشـان داد تمرينهاى حسى حركتى اسبار كك موجـب كاهش دشـــارى تنظيم هيجان در كود كان با اختلال نارســايى توجه - فزون كنشـى مى شــود. اين يافته ها با نتايج يثزوهش بيشـوبِ (Y9) مبنى بر اثربخشى مداخله آموزشى اسيارك بر تنظيم هيجان دانش آموزان مبتلابه اختلالات ياد گيرى همســو و همراســا اســت. در تبيين اين يافته مى توان بيـان كرد كه تحول مهارتهاى ادراكى -حر كتى در اين مطالعه كه حاصل اجراى برنامه اسِار كك بوده است، زمينه را جهت تحول طبيعى كود كان با اختلال نارسـايى توجه - فزون كنشى فراهم آورده است (Y9). فرايندهاى شـناختى و هيجانى از جمله مواردى هستند كه مىتوانند تحت تأثير تجربسها و ياد كيرىهاى ادراكى - حركتى كود كان قرار كيرند؛ به زبانى ديخر بايد بيان توجه داشـت زمانى كه فرد در فعاليت هاى ادراكى حر كتى شر كت مى كند، با فعال كردن قسمت هاى مختلف مغزى، توانايى او براى تشــخيص شـــوهــاى تنظيم هيجـان بهبود يـافتـه و هميجنين بـهـ برونريزى و تخليه هيجانى خود مى يردازد و در نتيجه فرد توانايى بيشترى در تنظيم هيجانهاى خود خواهد داشـت (YN). از سويى ديكر با توجه به نظريه تحولى بيازه مى توان بيان كرد كسـب تجربه و دخل و تصـرف در محيط (كـه از بيـامدهاى حركت اســت) در كود كان، زمينهســاز تحول 


\section{References}

1. Polanczyk GV, Willcutt EG, Salum GA, Kieling C, Rohde LA. ADHD prevalence estimates across three decades: an updated systematic review and metaregression analysis. International journal of epidemiology. 2014; 43(2):434-42. Doi.org/10. 1093/ ije/dyt261 [Link]

2. Liu Y, Hanna GL, Hanna BS, Rough HE, Arnold PD, Gehring WJ. Behavioral and Electrophysiological Correlates of Performance Monitoring and Development in Children and Adolescents with Attention-Deficit/Hyperactivity Disorder. Brain Sciences. 2020; 10(2):79. Doi.org/10. 3390/ brainsci 10020079 [Link]

3. Schatz NK, Aloe AM, Fabiano GA, Pelham Jr WE, Smyth A, Zhao X, et al. Psychosocial Interventions for Attention-Deficit/Hyperactivity Disorder: Systematic Review with Evidence and Gap Maps. Journal of Developmental \& Behavioral Pediatrics. 2020; 41:S77-S87. Doi: 10.1097/DBP.0000000000000778 [Link]

4. Faraone SV, Larsson H. Genetics of attention deficit hyperactivity disorder. Molecular psychiatry. 2019; 24(4):562-75. doi.org/10.1038/s41380-018-0070-0 [Link]

5. Bunford N, Evans SW, Wymbs F. ADHD and emotion dysregulation among children and adolescents. Clinical child and family psychology review. 2015; 18(3):185-217. Doi.org/10. 1007/s10567-015-0187-5 [Link]

6. Bunford N, Evans SW, Zoccola PM, Owens JS, Flory $\mathrm{K}$, Spiel CF. Correspondence between heart rate variability and emotion dysregulation in children, including children with ADHD. Journal of abnormal child psychology. 2017; 45(7):1325-37. Doi.org/ 10. 1007/s10802-016-0257-2 [Link]

7. Graziano PA, Garcia A. Attention-deficit hyperactivity disorder and children's emotion dysregulation: A meta-analysis. Clinical psychology review. 2016; 46:106-23. doi.org/10.1016/ j.cpr. 2016. 04.011 [Link]

8. Okado I, Mueller CW. The relationship between childreported positive affect and parent-reported emotional and behavioral problems in ADHD youth. Journal of Child and Family Studies. 2016; 25(10):2954-65. doi.org/10.1007/s10826-016-0458-x [Link]

9. Gyurak A, Gross JJ, Etkin A. Explicit and implicit emotion regulation: a dual-process framework. Cognition and emotion. 2011; 25(3):400-12. Doi. org/ 10. 1080/02699931.2010. 544160 [Link]
10.Cracco E, Van Durme K, Braet C. Validation of the FEEL-KJ: an instrument to measure emotion regulation strategies in children and adolescents. PloS one. 2015 ; 10(9):e0137080. DOI: 10.1371/ journal. pone. 0137080 [Link]

11. Theule J, Wiener J, Tannock R, Jenkins JM. Parenting stress in families of children with ADHD: A metaanalysis. Journal of Emotional and Behavioral Disorders. 2013; 21(1):3-17. doi.org/10.1177/ 10634 26610387433 [Link]

12. Valipour M, Hosseinian S, Pourshahriari M. The effectiveness of cognitive therapy based on mindfulness on children's behavioral problems. Quarterly Journal of Child Mental Health. 2018; 4(4):34-45. [Link]

13. Burdick DL. Mindfulness s kills for kids \& teens: A workbook for clinicians \& clients with 154 tools, techniques, activities \& worksheets: PESI Publishing \& Media; 2014. [Link]

14. Yang E, Schamber E, Meyer RM, Gold JI. Happier healers: randomized controlled trial of mobile mindfulness for stress management. The Journal of Alternative and Complementary Medicine. 2018; 24(5):505-13. doi.org/10.1089/acm.2015.0301 [Link]

15. Woods BK, Sauer-Zavala S, Farchione TJ, Barlow DH. Isolating the Effects of Mindfulness Training Across Anxiety Disorder Diagnoses in the Unified Protocol. Behavior Therapy. 2020. doi.org/10.1016/ j.beth.2020.01.001 [Link]

16.Iani L, Lauriola M, Chiesa A, Cafaro V. Associations between mindfulness and emotion regulation: the key role of describing and non-reactivity. Mindfulness. 2019; 10(2):366-75. doi.org/10.1007/s12671-0180981-5 [Link]

17. Kiani B, Hadianfard H. The impact of therapy based on mindfulness meditation training on emotion dysregulation in subclinical ADHD adolescents. 2016. [Link]

18. Roemer L, Williston SK, Rollins LG. Mindfulness and emotion regulation. Current Opinion in Psychology. 2015; 3:52-7. doi.org/10.1016/j.copsyc.2015.02.006 [Link]

19.Butler RM, Boden MT, Olino TM, Morrison AS, Goldin PR, Gross JJ, et al. Emotional clarity and attention to emotions in cognitive behavioral group therapy and mindfulness-based stress reduction for social anxiety disorder. Journal of anxiety disorders. 2018; 55:31-8. doi.org/10.1016/j.janxdis.2018.03.003 [Link]

20.Slutsky J, Rahl H, Lindsay EK, Creswell JD. Mindfulness, emotion regulation, and social threat. 
Mindfulness in social psychology: Routledge; 2017. p. 79-93. [Link]

21.Britton WB, Shahar B, Szepsenwol O, Jacobs WJ. Mindfulness-base cognitive therapy improves emotional reactivity to social stress: results from a randomized controlled trial. Behavior therapy. 2012; 43(2):365-80. Doi.org/10.1016/j.beth.2011.08.006 [Link]

22. Heinrich H, Strehl U, Arns M, Rothenberger A, Ros T. Neurofeedback in ADHD. Lausanne: Frontiers Media. 2016. Doi: 10.3389/978-2-88919-722-4 [Link]

23. Schwartz MS, Andrasik F. Biofeedback: A practitioner's guide: Guilford Publications; 2017. DOI: 10.1037/004502 [Link]

24. Cortese S, Ferrin M, Brandeis D, Holtmann M, Aggensteiner P, Daley D, et al. Neurofeedback for attention-deficit/hyperactivity disorder: meta-analysis of clinical and neuropsychological outcomes from randomized controlled trials. Journal of the American Academy of Child \& Adolescent Psychiatry. 2016; 55(6):444-55. doi.org/10.1016/j.jaac.2016.03.007 [Link]

25. Ghayour Kazemi F, Sepehri Shamloo Z, Mashhadi A, Ghanaei Chamanabad A, Pasalar F. A Comparative Study Effectiveness of Metacognitive Therapy with Neurofeedback Training on Anxiety Symptoms, Emotion Regulation and Brain wave activity in Female Students with Social Anxiety Disorder (Single Subject Study). Neuropsychology. 2018; 4(12):77100. [Link]

26. Villa-Gonzalez R, Villalba-Heredia L, Crespo I, del Valle M, Olmedillas H. A systematic review of acute exercise as a coadjuvant treatment of ADHD in young people. Psicothema. 2020; 32(1):67-74. Doi: 10.7334/ psicothema2019.211 [Link]

27. Hemayattalab R, Homayounnia M, Zandi S. Effects of SPARK Physical Education Program on Behavioral Problems of Children with ADHD. International Journal of Psychology.10 (2):17-32. [Link]
28.Chen Q. Intervention Study of Sports Games in Rehabilitation of CHILDREN with Autism. Investigación Clínica. 2019; 60(1) [Link]

29.Bishop JA. SPARK for Learning: Examining Emotion Regulation in Children with SLD: Graduate Studies; 2015. dx.doi.org/10.11575/PRISM/27842 [Link]

30. Nagae M, Nakane H, Honda S, Ozawa H, Hanada H. Factors affecting medication adherence in children receiving outpatient pharmacotherapy and parental adherence. Journal of Child and Adolescent Psychiatric Nursing. 2015; 28(2):109-17. doi.org/ 10. 1111/jcap.12113 [Link]

31. Coghill D. Drug treatments for child and adolescent disorders. Fundamentals of Clinical Psychopharmacology: CRC Press; 2019. p. 144-54. [Link]

32. Martel MM. The Clinical Guide to Assessment and Treatment of Childhood Learning and Attention Problems: Academic Press; 2020. [Link]

33.Halperin JM, Healey DM. The influences of environmental enrichment, cognitive enhancement, and physical exercise on brain development: Can we alter the developmental trajectory of ADHD? Neuroscience \& Biobehavioral Reviews. 2011; 35(3):621-34. doi.org/10.1016/j.neubiorev.2010.07.006 [Link]

34.Bunford N, Dawson AE, Evans SW, Ray AR, Langberg JM, Owens JS, et al. The difficulties in emotion regulation scale-parent report: A psychometric investigation examining adolescents with and without ADHD. Assessment. 2018. doi.org/10.1177/1073191118792307 [Link]

35. Chen H, Sun H. Effects of active videogame and sports, play, and active recreation for kids' physical education on children's health-related fitness and enjoyment. Games for Health Journal. 2017; 6(5):3128. doi.org/10.1089/g4h.2017.0001 [Link]

36.Demos J. N. Getting Started with Neurofeedback. New York: WW Norton \& Company, 2005 [Link] 